\title{
A LITERATURE REVIEW ON BUILDING A FUTURE TOWARDS ENGINEERING
}

\author{
Rauak Mishra \\ Department of Plus Two \\ St. Xavier's College, Kathmandu, Province-3, Nepal
}

\author{
Ram Sundar Matang \\ Department of Physics \\ St. Xavier's College, Kathmandu, Province-3, Nepal
}

\begin{abstract}
In the present context of Nepal, students face various problems for choosing the correct subject after their higher secondary studies. As a student of Physics, I and most of the students look forward to their career in different fields of Engineering. In this paper we'll discuss the different types of Engineering and compare the aspects of building the future in each field in the context of the world and compare it with the perspective of Nepal.
\end{abstract}

The main purpose of the study is to help the upcoming generations to choose a better field of engineering and make them realize their own qualities and strength. As well as this will also develop a basic idea in them about what they need to know before choosing their major.

The paper contains the history of engineering in the world and how it developed in Nepal, requisite and prerequisite, qualities to be an engineer, comparison of salaries of different engineers in Nepal with respect to the world, benefits of Engineering and more.

Going through the paper, we'll also come through various results and data collected from primary sources through a sample survey of about 30-35 engineering candidates. We also found that most of the people faced various problems after selecting a major without complete research and information about the field.

Finally, we'll come to a conclusion with a list of things to consider before building your future towards engineering.

Keywords - Engineering, History, Types, Qualities

\section{INTRODUCTION TO ENGINEERING}

Engineering is the use of scientific principles to design and build machines, structures, and other items, including bridges, tunnels, roads, vehicles, and buildings. The discipline of engineering encompasses a broad range of more specialized fields of engineering, each with a more specific emphasis on particular areas of applied mathematics, applied science, and types of application.

The term engineering is derived from the Latin word ingenium, meaning "cleverness" and ingeniare, meaning "to contrive, devise".
Someone who uses Engineering Problem Solving techniques to develop and improve consumer products, drugs (the good kind), factory processes, buildings and bridges, computer programs, electronics is an Engineer.

\section{HISTORY OF ENGINEERING}

The concept of engineering has existed since ancient times as humans devised fundamental inventions such as the pulley, lever, and wheel. Each of these inventions is consistent with the modern definition of engineering, exploiting basic mechanical principles to develop useful tools and objects.

The term engineering itself has a much more recent etymology, deriving from the word engineer, which itself dates back to 1325, when an engineer (literally, one who operates an engine) originally referred to "a constructor of military engines". The word "engine" itself is of even older origin, ultimately deriving from the Latin ingenium (c. 1250), meaning "innate quality, especially mental power, hence a clever invention."

Later, as the design of civilian structures such as bridges and buildings matured as a technical discipline, the term civil engineering entered the lexicon as a way to distinguish between those specializing in the construction of such non-military projects and those involved in the older discipline of military engineering (the original meaning of the word "engineering," now largely obsolete, with notable exceptions that have survived to the present day).

Advances were made in all areas, including technologies that transformed everyday activities. For example, in:

- 1851 , Isaac Singer patents a continuous stitch sewing machine

- 1868 , Christopher Sholes patents the first practical typewriter

- 1873 , Andrew Hallidie invents cable cars for use in San Francisco

- $\quad 1874$, Joseph Glidden invented barbed wire

- 1876, Alexander Graham Bell patents the telephone

- 1884 , Lewis E Waterman patents a practical fountain pen

III. HOW TO BE AN ENGINEER?

1. Earn a graduate degree: Many engineering management roles and higher require a master's degree. Not 
only does a graduate degree convey to companies that you have the technical ability and knowledge needed to lead, studying for one also helps you develop leadership skills in class. Through group work on collaborative engineering projects, students get to practice for real-world leadership roles.

2. Network: Networking inside and outside of the workplace is essential for engineering leaders. Learning about the work that is going on in your industry can clue you in to trends that will affect your own work, and you can also form relationships with people who may be able to refer you to or hire you for management roles in the future.

3. Work on what you're passionate about: If you're currently working in an engineering role, volunteer for projects that sound exciting or in which you can lead small groups. Working on tasks that inspire you will make it easier to show your own managers where you excel and what potential you have as a leader. Go above and beyond what is expected of you in your current role so that you stand out when management roles open up, or so that you can list your accomplishments on a resume when looking for other positions.

\section{DIFFERENT TYPES OF ENGINEER IN THE WORLD}

In a survey I made, a maximum number of people were familiar with only 10-20 branches of Engineering. So, it became very important to list out the major branches and their sub-branches in this research article.
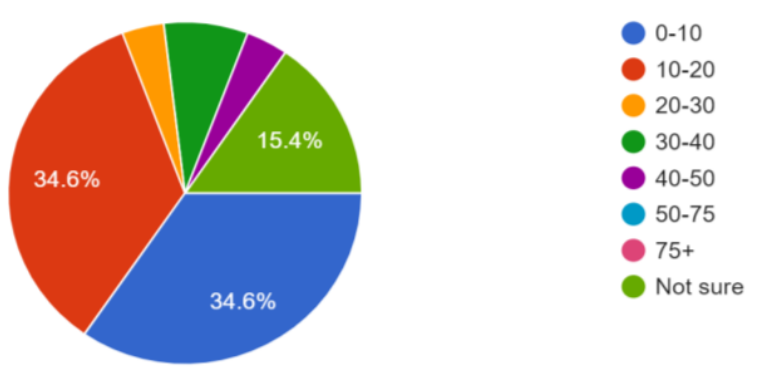

A List of different types of engineering in the world is presented hereunder:

\begin{tabular}{|l|l|l|}
\hline S.N. & $\begin{array}{l}\text { Major Engineering } \\
\text { Branches }\end{array}$ & Sub-Branches \\
\hline 1. & $\begin{array}{l}\text { Chemical } \\
\text { Engineering }\end{array}$ & $\begin{array}{l}\text { Biomolecular } \\
\text { Engineering }\end{array}$ \\
\hline & & $\begin{array}{l}\text { Materials } \\
\text { Engineering }\end{array}$ \\
\hline & & $\begin{array}{l}\text { Molecular } \\
\text { Engineering }\end{array}$ \\
\hline & & Process Engineering \\
\hline & & Corrosion \\
\hline
\end{tabular}

\begin{tabular}{|c|c|c|}
\hline & & Engineering \\
\hline \multirow[t]{9}{*}{2.} & Civil Engineering & \\
\hline & & $\begin{array}{l}\text { Architectural } \\
\text { Engineering }\end{array}$ \\
\hline & & $\begin{array}{l}\text { Environmental } \\
\text { Engineering }\end{array}$ \\
\hline & & $\begin{array}{l}\text { Geotechnical } \\
\text { Engineering }\end{array}$ \\
\hline & & $\begin{array}{l}\text { Structural } \\
\text { Engineering }\end{array}$ \\
\hline & & Mining Engineering \\
\hline & & $\begin{array}{l}\text { Transport } \\
\text { Engineering }\end{array}$ \\
\hline & & Utility Engineering \\
\hline & & $\begin{array}{l}\text { Water Resources } \\
\text { Engineering }\end{array}$ \\
\hline \multirow[t]{6}{*}{3.} & $\begin{array}{l}\text { Electrical } \\
\text { Engineering }\end{array}$ & \\
\hline & & $\begin{array}{l}\text { Electronic } \\
\text { Engineering }\end{array}$ \\
\hline & & $\begin{array}{l}\text { Computer } \\
\text { Engineering }\end{array}$ \\
\hline & & Power Engineering \\
\hline & & Optical Engineering \\
\hline & & $\begin{array}{l}\text { Electrical and } \\
\text { Electronics } \\
\text { Engineering }\end{array}$ \\
\hline \multirow[t]{6}{*}{4.} & $\begin{array}{l}\text { Mechanical } \\
\text { Engineering }\end{array}$ & \\
\hline & & $\begin{array}{l}\text { Acoustical } \\
\text { Engineering }\end{array}$ \\
\hline & & $\begin{array}{l}\text { Manufacturing } \\
\text { Engineering }\end{array}$ \\
\hline & & $\begin{array}{l}\text { Optomechanical } \\
\text { Engineering }\end{array}$ \\
\hline & & Thermal Engineering \\
\hline & & Sports Engineering \\
\hline
\end{tabular}


International Journal of Engineering Applied Sciences and Technology, 2020

Vol. 5, Issue 4, ISSN No. 2455-2143, Pages 82-90

Published Online August 2020 in IJEAST (http://www.ijeast.com)

\begin{tabular}{|c|c|c|}
\hline & & Vehicle Engineering \\
\hline & & $\begin{array}{l}\text { Powerplant } \\
\text { Engineering }\end{array}$ \\
\hline & & Energy Engineering \\
\hline 5. & Interdisciplinary & \\
\hline & & $\begin{array}{l}\text { Aerospace } \\
\text { Engineering }\end{array}$ \\
\hline & & $\begin{array}{l}\text { Agricultural } \\
\text { Engineering }\end{array}$ \\
\hline & & Applied Engineering \\
\hline & & Audio Engineering \\
\hline & & $\begin{array}{l}\text { Automotive } \\
\text { Engineering }\end{array}$ \\
\hline & & $\begin{array}{l}\text { Biomedical } \\
\text { Engineering }\end{array}$ \\
\hline & & $\begin{array}{l}\text { Biomedical Nano- } \\
\text { Engineering }\end{array}$ \\
\hline & & $\begin{array}{l}\text { Biological } \\
\text { Engineering }\end{array}$ \\
\hline & & $\begin{array}{l}\text { Building Services } \\
\text { Engineering }\end{array}$ \\
\hline & & Energy Engineering \\
\hline & & $\begin{array}{l}\text { Information } \\
\text { Engineering }\end{array}$ \\
\hline & & $\begin{array}{l}\text { Industrial } \\
\text { Engineering }\end{array}$ \\
\hline & & $\begin{array}{l}\text { Mechatronics } \\
\text { Engineering }\end{array}$ \\
\hline & & Marine Engineering \\
\hline & & $\begin{array}{l}\text { Mining and } \\
\text { Geological } \\
\text { Engineering }\end{array}$ \\
\hline & & Nano Engineering \\
\hline & & Nuclear Engineering \\
\hline & & $\begin{array}{l}\text { Petroleum } \\
\text { Engineering }\end{array}$ \\
\hline
\end{tabular}

\begin{tabular}{|l|l|l|}
\hline & & Project Engineering \\
\hline & & Railway Engineering \\
\hline & & $\begin{array}{l}\text { Software } \\
\text { Engineering }\end{array}$ \\
\hline & & $\begin{array}{l}\text { Supply Chain } \\
\text { Engineering }\end{array}$ \\
\hline & & Systems Engineering \\
\hline & & $\begin{array}{l}\text { Telecommunications } \\
\text { Engineering }\end{array}$ \\
\hline & & Textile Engineering \\
\hline 6. & Social Engineering & Reverse Engineering \\
\hline 7. & $\begin{array}{l}\text { Financial } \\
\text { Engineering }\end{array}$ & \\
\hline & &
\end{tabular}

V. SCOPES OF VARIOUS ENGINEERING

In Nepal, according to the Central Bureau of Statistics 2014, the illiterate unemployment (unemployed and illiterate) is 2.1 per cent in the country, whereas literate/educated unemployment (unemployed despite having a college degree) rate is 4.1 percent.

01. Mechanical Engineering:

After completing this programme, students can work in the following industries:

- Machinery manufacturing

- Scientific research and development

- Automotive industry

- Construction and building

- Aerospace

- Maintenance Engineer

- Nuclear Engineer

- CAD Technician

- Control and Instrumentation Engineer

- Automotive Engineer

02. Electronics and Telecommunications:

These experts can work in the following fields:

- Telecommunications and IT

- Manufacturing

- Quality Assurance

- Utilities

- Consumer goods production

- Electronics Engineer

- System Control Engineer

- Test and Integration Engineer

- Electronics design and Development Engineer

- Wireless communication

- Satellite communication 


\section{International Journal of Engineering Applied Sciences and Technology, 2020 \\ Vol. 5, Issue 4, ISSN No. 2455-2143, Pages 82-90 \\ Published Online August 2020 in IJEAST (http://www.ijeast.com)}

- Microwave communication

- Automation

- Robotics

- Machine Learning

- Data Science

- $\quad$ PLC, FPGA

\section{Civil Engineering:}

These professionals are required in the following domains:

- Construction

- Transport and Communications Infrastructure

- Coastal and Marine

- Energy and power

- Geotechnical

- Consulting Civil Engineer

- Design Engineer

- Nuclear Engineer

- Site Engineer

- Structural Engineer

- Constructing quality roads

\section{4. $\quad$ Computer Science Engineering:}

After the completion of this course, students can work in the following areas:

- Manufacturing

- Product development

- Cybersecurity

- Operating systems and networks

- Robotics

- Software Developer

- Computer Network Architect

- Mobile Application Developer

- Computer Hardware Engineer

- $\quad$ IT Project Manager

05. Information Technology:

Information Technologists are required in the following industries:

- Data processing and hosting

- Telecommunications

- Education, Finance and Insurance

- Database Designer

- Computer Programmer

- System Administrator

- Quality Assurance Specialist

- Network Architect

06.

\section{Aerospace Engineering:}

- Airlines

- Air Force

- Research Companies

- Helicopter Companies

- $\quad$ Aircraft Manufacturers

\section{Electrical Engineering}

They create electrical systems used in products which are then designed, developed and tested. These engineers find the most suitable ways to use electrical power. The process involves calculations to develop and build products; arrive at specifications for manufacturing and installation of a product; and testing products to ensure they meet the production criteria. In the context of Nepal it has a very good scope in Hydropower Plants and NEA.

\section{Environmental Engineering}

In case of an environmental adversity, such as an oil spill, a community turns to these kinds of engineers for support. They are handy when a city needs to improve its recycling program. Some of the specific job duties of environmental engineers include conducting environmental investigations, creating environmental protection plans, and inspecting industrial facilities to ensure they comply with applicable laws.

\section{Nuclear Engineering:}

These engineers develop ways to leverage nuclear energy and radiation. Their work can be found in medical devices used to treat and diagnose patients, as well as power sources found in airplanes and ships. Some of the Nuclear Engineer job roles include design and development of equipment such as radiation sheltering, reactor cores; examining the nuclear accidents to find the cause and to create prevention policies; scripting guidelines for nuclear waste handling and disposal rule and also to mentor the operations of nuclear power plants in order to ensure its smooth and lawful functioning.

\section{9. $\quad$ Materials Engineering:}

Material engineers make use of material to create products used in everyday life - which is accomplished by developing, testing and processing materials in order to find the right elements for a specific product. Job roles of Material engineer comprise creating finances for projects and ensuring proper implementation of these projects; investigating product failures and finding the reason and solution for the failure and to also supervise the work of technicians and scientists.

\section{Industrial Engineering:}

They use their domain knowledge to manage materials, devices, information and even people in order to create products or provide services. The job of an Industrial Engineer demands the review of processes in order to uncover the wastefulness, creating efficient ways to manufacture products, scrutinizing production issues and implementation of quality control measures. Streamlining the production schedule is also one of the roles involved in the job profile of Industrial engineers.

\section{Chemical Engineering:}

Chemical engineers work in laboratories to create experiments which results in reducing the gap in investigation and manufacturing of chemical goods and apparatus. Scope of work is from optimizing DNA order to discovering an alternative for gasoline. Chemical Engineering encompasses the study of Chemistry, Biology, Math and Engineering Sciences. Students learn to create new medicines and fertilizers, optimize resource productivity or manage compound plants and industries.

\section{Automobile Engineering:}

These engineers work on design and creation of automobiles 


\section{International Journal of Engineering Applied Sciences and Technology, 2020 \\ Vol. 5, Issue 4, ISSN No. 2455-2143, Pages 82-90 \\ Published Online August 2020 in IJEAST (http://www.ijeast.com)}

which run on different energy sources to travel faster and smarter with comfort. They can work as a design engineer to develop new designs for vehicles, or in the production department giving shape to the design or in the testing department analyzing the loopholes in the design and manufacturing. All departments are inter related and each one should know all the jobs to excel better.

\section{Biotechnology Engineering:}

Biotechnology is a branch where you study how to work on chemical compositions and structure to create better molecules. Engineers in the subject implement these compositions to manufacture products to masses. The subject has a mixer of chemical, biology and engineering.

\section{Production Engineering:}

A Production Engineer is responsible for safe manufacturing equipment and production processes with cost effectiveness. The work is normally involved in areas like Installation and maintenance. Maintenance involves working with Technicians to resolve problems with the plant or machinery. Installation involves purchase of new machinery and deciding is optimal utilization.

\section{Agricultural Engineering:}

It is the branch of engineering which helps in planning and supervising to develop agricultural production. In this, engineers suggest the best ways to optimize the resources and make the process smoother.

\section{6. $\quad$ Architectural Engineering:}

This branch of engineering is multitasking as it includes designing, planning, maintaining the space, material and providing a proper structure to the building. Also, the field research, selecting the site, safety, quality, costing as well as the overall construction comes under Architecture Engineering.

\section{Biomedical Engineering:}

It is a multidisciplinary subject. Along with Biology it requires the knowledge of different fields of engineering like Electronics, Electrical and Computer. As far as Biology is concerned, candidates should have the knowledge about tissue engineering, cell biology, genetic engineering and biomaterials.

\section{Marine Engineering:}

Marine engineering is the branch which deals with the designing, building, testing and repairing of boats, ships, underwater craft, and offshore platforms and drilling equipment. Institutions like International Maritime Academy recruit marine engineers to the post of junior engineers in merchant ships. There are also lucrative career options in public and private shipping companies, engine production firms, ship building and designing firms, navy and research bodies.

After graduating as a marine engineer, one can get a job in a ship as an engineer. They can also get employed in different shipping companies.

\section{Automation and Robotics Engineering:}

Robots are increasingly becoming a key part of most production and manufacturing companies. Robotics is a rapidly growing field full of opportunities for engineering students who have good aptitude and a creative mind. Industries across a range of sectors such as automotive, atomic energy, defence, space, metals, textiles and manufacturing use Robotic technologies very extensively.

With global players, like Google investing in Robotics and several open source tools and platforms available for robotics - there is going to be significant development in this field in another 5-10 years. Some of the possible job roles include, Robot Design Engineer, Flexible Manufacturing Engineer, Automated Product Design Engineer, Artificial Intelligence Thinking Machines and Systems, Space survey \& Analysis Engineer and System Design \& Analysis Engineer.

\section{QUALITIES OF AN ENGINEER}

01. Focus:

Focus and attention to details are essential to get the job done accurately, safely, and on time.

\section{STEM Skill:}

STEM (Science, Technology, Engineering, and Mathematics) skills are what fuel the complex mind of engineers. STEM education creates critical thinkers, increases science literacy, and enables the next generation of innovators.

Innovation leads to new products and processes that sustain our economy. This innovation and science literacy depends on a solid knowledge base in the STEM areas. STEM education helps to bridge the ethnic and gender gaps sometimes found in math and science fields.

\section{Can debug anything quickly:}

"The quicker you can fix, the more time you can spend building value.", and the less trust you lose with your customers. The better you fix, and simplify, the more time you free up in the future that may otherwise have been spent fighting further regressions. Good fixes come from those who deeply understand the problem.

\section{Logical Thinking and Reasoning;}

A great engineer needs to be able to comprehend complex systems, how they work, how problems arise and how to fix them.

\section{Attention to detail:}

Paying attention to the minutest of details throughout the course of any project is crucial in engineering because the cost of making even the slightest of errors is huge.

\section{Creativity and Innovation:}

A competent engineer is always creative enough to think outside of the box and device ways and means to improve existing systems and innovate new ones.

\section{Team Player:}

It goes saying; you can go further when you work together. Any project that is completed successfully and efficiently has a great team, and not just one person, working behind it. 


\section{International Journal of Engineering Applied Sciences and Technology, 2020 \\ Vol. 5, Issue 4, ISSN No. 2455-2143, Pages 82-90 \\ Published Online August 2020 in IJEAST (http://www.ijeast.com)}

08. $\quad$ Practical and Resourceful:

When issues arise, an engineer must be able to think quickly and use what they have to solve the problem. Engineers are able to think out of the box and apply their knowledge in practical and resourceful ways.

\section{Ethical:}

Engineers frequently work to solve problems for people. Thus it is essential for engineers to always follow the rules and complete work in an ethical manner, keeping everyone safe and happy.

10. Open mind and positive attitude:

If engineers are to solve challenging technical problems, they should be imaginative and optimistic. It is this attitude that can enable them to be successful.

\section{Communication skills:}

Work doesn't happen in a vacuum. Engineers need strong communication skills to work with clients, team members, and supervisors effectively and efficiently. They also relay project parameters and deadlines to their reports, while providing updates to their managers and clients. Moreover, regular communication builds trust and makes it easier for all team members to do their jobs well. For engineers to be successful over the course of their careers, communication skills are just as important as technical knowledge. This is certainly the case in engineering firms, where collaboration is key.

\section{2. $\quad$ Ambitious and Determined;}

Great companies have huge ambition - which initially comes from awesome founders, but is sustained and thrives with the addition of ambitious people they hire.

"Ambition is a ceiling to success."

\section{Analytical Ability;}

Engineers are required to think analytically in order to fully define a problem and develop solutions suited to the problem.

$$
\text { VII. SOME IMPORTANT FAQS }
$$

A. Is Internship or consulting an academic advisor necessary? Academic Advising is necessary for following reasons:

- To confirm the academic requirements for your degree

- To make sure you are enrolled in the right classes

- To explore major and career options

- To plan future steps in your education

- To become familiar with student information systems, such as Banner and GradesFirst

- To make connections between challenging academic work and your future success

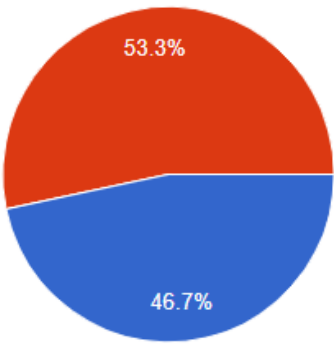

Yes But in a survey No

I made only $46.7 \%$ students consulted their academic advisor while $53.3 \%$ didn't as shown in the pie chart on the above.

And also only $40 \%$ people did internships whereas $60 \%$ didn't as shown in the piechart alongside. Studying Theories in books and practising in real life are two different things. Those who didn't do internships confessed that they had to face more problems during job placement and start to work at low salary due to lack of experience.

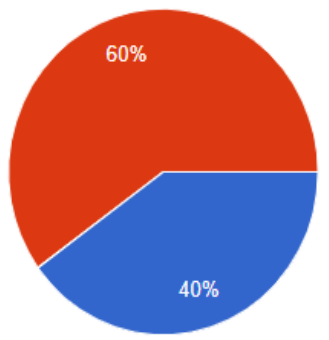

Internships are necessary for the following reasons:

- To learn corporate working practice

- Internships lead to effectiveness in a particular sector of job

- Internships teach you what actually happens in the real world, not the college

- For practical exposure, and enhancing soft skills

- To Learn More About Yourself

- Get Connected and Develop Your Professional Network

- To prevent CV From Going To The Trash

- Gain experience and increase marketability

- Learn how a professional workplace operates

To avoid facing problems in the upcoming future, it's better to consult your academic advisor for suggestions before choosing your major subject. Also, doing an internship during your course or after it may help you during job placement and work as well and also add a star to your resume.

\section{B. Is Research necessary?}

In a survey, I conducted among 30 people who have already been or are willing to be an engineer, only $57.9 \%$ of them have conducted research before choosing their field whereas the rest $42.1 \%$ didn't.

But It is very much important to make research before you select a particular field about its future scope because the world is changing gradually and the field that has a great scope today mayn't have much scope in the upcoming days when you complete your study. 


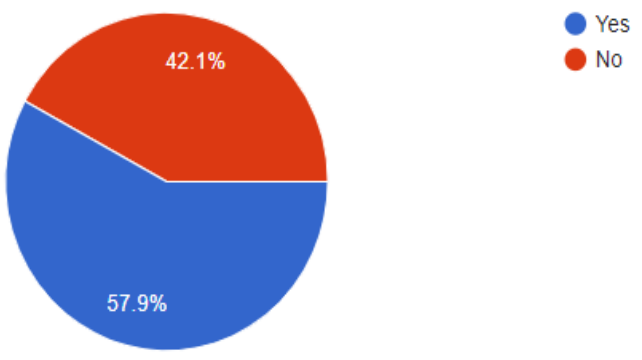

So, it is much beneficial to have some research and survey about the change in future scopes and remuneration of your field.

\section{Why choose Engineering?}

In the survey I made, only $71.4 \%$ of people choose engineering because of their passion and they love Engineering while others chose it for various other reasons like for better salary, respect in society, better job opportunities, etc. while few of them even don't know why they chose Engineering.

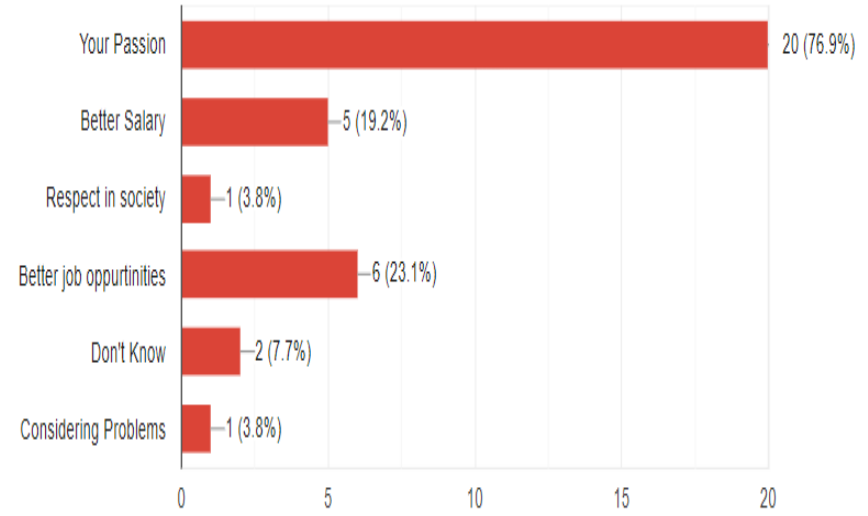

It is generally recommended that before choosing your field of study, you must know why you are choosing that and what qualities do you need to choose it. Before choosing a particular field you must be clear that you choose it for your personal happiness not because of family pressure, or because your friends or relative chose that field. You should choose a field only if you've an interest in it and you like being engaged in that.

D. Requirement of Self-Confidence in Maths and Science In my survey I found that only $14.3 \%$ of engineering fans are 80-100\% confident in their Science and Maths problem solving skills. Most of them (42.9\%), as shown in the graph alongside, are about $60-80 \%$ confident. 15

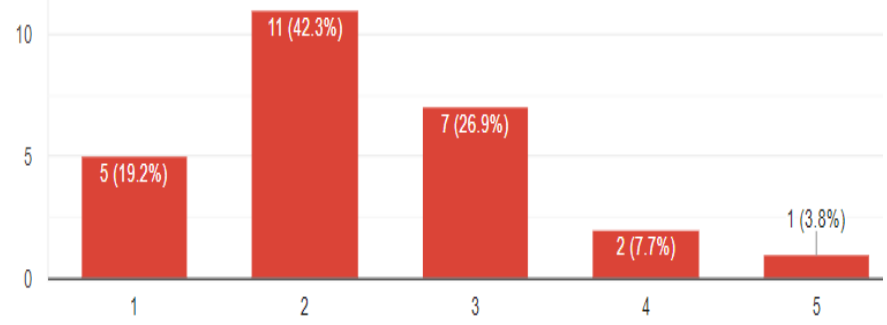

It is most important for an engineer in Maths and Science problem solving skills because STEM skills are what fuel the complex mind of engineers. Engineers frequently work to solve problems for people. It is important to identify when a problem exists, Evaluate relevant information, then Assess alternatives and impacts, Act decisively and re-assess the situation.

\section{BENEFITS OF ENGINEERING}

- Challenging (You Don’t Get Bored)

- Flexible Job Opportunities

- Good Pay and Benefits

- Lasting and Tangible Products

- Help to humankind

- International opportunities

- Intellectual Development

- Potential to Benefit Society

- Technological and Scientific Discovery

- Develop Creative Thinking

- Every day is different

- The job always evolves and changes

\section{ENGINEERING IN NEPAL}

"Engineering!" is the most common answer you will get if you ask a science student of +2 in Nepal what s/he wants to study after completing their intermediate level. Engineering is gaining more popularity with the increase in colleges and institutions that teach Engineering in Nepal and their effort to attract more students. The scope of Engineering in Nepal is also increasing with the increase in developmental activities, although it is at a slow rate.

About 1000 Engineers are produced each year in Nepal (According to an article in the Kathmandu Post).

\section{HISTORY OF ENGINEERING IN NEPAL}

In 1972, the Nepal Engineering Institute at Pulchowk and the Technical Training Institute at Thapathali were brought together under the umbrella of the Tribhuvan University to constitute the Institute of Engineering and the Nepal Engineering Institute and the Technical Training Institute were renamed as Pulchowk Campus and Thapathali Campus respectively.

The technician programs in Electrical, Electronics, Refrigeration/Air-conditioning Engineering were started in the Pulchowk Campus, with the assistance from UNDP/ILO. From the academic year 1998/99 IOE has started a Bachelor's Degree program in Computer Engineering. In 1996 Pulchowk Campus, with support from the Norwegian Government, started M.Sc. Courses in Urban Planning, Structural Engineering, Environmental Engineering and Water Resources Engineering Pulchowk Campus have also started M.Sc. courses in Renewable energy and Geothermal Engineering, Information and communication and Power systems Engineering effective from December, 2001. The diploma level programs at the Pulchowk Campus have been transferred to other three IOE campuses.

The Thapathali Campus is presently offering three-year Diploma level courses in Mechanical, Automobile, Civil Engineering and Architecture. 
International Journal of Engineering Applied Sciences and Technology, 2020

Vol. 5, Issue 4, ISSN No. 2455-2143, Pages 82-90

Published Online August 2020 in IJEAST (http://www.ijeast.com)

XI. NAME OF SOME COLLEGES AFFILIATED TO DIFFERENT UNIVERSITIES IN NEPAL

\begin{tabular}{|c|c|c|}
\hline S.N. & Name of Universities & $\begin{array}{l}\text { Name of Colleges } \\
\text { Affiliated }\end{array}$ \\
\hline \multirow[t]{10}{*}{1.} & Tribhuvan University & \\
\hline & & $\begin{array}{l}\text { Pulchowk Campus, } \\
\text { Institute of } \\
\text { Engineering(IoE) }\end{array}$ \\
\hline & & $\begin{array}{l}\text { Kathmandu Engineering } \\
\text { College }\end{array}$ \\
\hline & & $\begin{array}{l}\text { Sagarmatha Engineering } \\
\text { College }\end{array}$ \\
\hline & & $\begin{array}{l}\text { Lalitpur Engineering } \\
\text { College }\end{array}$ \\
\hline & & $\begin{array}{l}\text { National College of } \\
\text { Engineering }\end{array}$ \\
\hline & & $\begin{array}{l}\text { Himalaya College of } \\
\text { Engineering }\end{array}$ \\
\hline & & $\begin{array}{l}\text { Kantipur Engineering } \\
\text { College }\end{array}$ \\
\hline & & $\begin{array}{l}\text { Kathford International } \\
\text { College of Engineering } \\
\text { and Management }\end{array}$ \\
\hline & & $\begin{array}{l}\text { Khwopa College of } \\
\text { Engineering }\end{array}$ \\
\hline \multirow[t]{7}{*}{2.} & Pokhara University & \\
\hline & & $\begin{array}{l}\text { Nepal Engineering } \\
\text { College }\end{array}$ \\
\hline & & $\begin{array}{l}\text { Gandaki College of } \\
\text { Engineering and Sciences }\end{array}$ \\
\hline & & $\begin{array}{l}\text { Khwopa Engineering } \\
\text { College }\end{array}$ \\
\hline & & $\begin{array}{l}\text { Everest Engineering } \\
\text { College }\end{array}$ \\
\hline & & $\begin{array}{l}\text { RITZ College of } \\
\text { Engineering and } \\
\text { Management }\end{array}$ \\
\hline & & $\begin{array}{l}\text { Nepal College of } \\
\text { Information Technology }\end{array}$ \\
\hline
\end{tabular}

\begin{tabular}{|l|l|l|}
\hline 3. & Purbanchal University & $\begin{array}{l}\text { Pokhara University } \\
\text { School of Engineering }\end{array}$ \\
\hline & & $\begin{array}{l}\text { Aryan School of } \\
\text { Engineering and } \\
\text { management }\end{array}$ \\
\hline & & $\begin{array}{l}\text { Kantipur International } \\
\text { College }\end{array}$ \\
\hline & & $\begin{array}{l}\text { College of Biomedical } \\
\text { Engineering and Applied } \\
\text { Sciences }\end{array}$ \\
\hline & & $\begin{array}{l}\text { Hillside College of } \\
\text { Engineering }\end{array}$ \\
\hline 4. & Kathmandu University & $\begin{array}{l}\text { Kantipur City } \\
\text { College(KCC) }\end{array}$ \\
\hline & & $\begin{array}{l}\text { Purbanchal University } \\
\text { School of Engineering } \\
\text { and Technology(PUSET) }\end{array}$ \\
\hline & & $\begin{array}{l}\text { Kathmandu University } \\
\text { School of Engineering }\end{array}$ \\
\hline
\end{tabular}

XII. A VERAGE SALARY OF VARIOUS ENGINEERS IN THE WORLD

A survey that I conducted among about 30 people only $57.1 \%$ people have reviewed the average salary potential before selecting their specific field of study while $42.9 \%$ of them haven't as shown in the chart alongside.

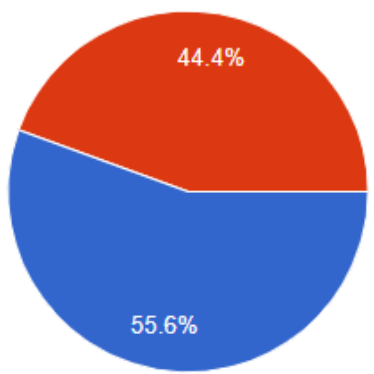

It is very important to know about how much you will be paid after a few years for a certain job you desire because money is very important for survival. You can't have food to eat, clothes to wear and home to live without money. If you want your desires to be fulfilled, you must review the salary potential of your field before selecting.

A person working in Engineering in Nepal typically earns around 96,500 NPR per month. Salaries range from 53,400 NPR (lowest average) to 128,000 NPR (highest average, actual maximum salary is higher). 
Engineering professionals in Nepal observe about a 5\% salary increment every 28 months on an average.

\begin{tabular}{|l|l|l|}
\hline S.N. & Branch of Engineering & $\begin{array}{l}\text { Average } \\
\text { Salary(p.a. })\end{array}$ \\
\hline 1. & Electrical Engineering & $\$ 97,970$ \\
\hline 2. & Software Engineering & $\$ 100,690$ \\
\hline 3. & Mechanical Engineering & $\$ 85,880$ \\
\hline 4. & Industrial Engineering & $\$ 85,880$ \\
\hline 5. & Aerospace Engineering & $\$ 113,030$ \\
\hline 6. & Chemical Engineering & $\$ 102,106$ \\
\hline 7. & Environmental Engineering & $\$ 86,800$ \\
\hline 8. & Agricultural Engineering & $\$ 74,780$ \\
\hline 9. & Petroleum Engineering & $\$ 132,280$ \\
\hline 10. & Geological Engineering & $\$ 84,320$ \\
\hline 11. & Biomedical Engineering & $\$ 88,040$ \\
\hline 12. & Automotive Engineering & $\$ 82,200$ \\
\hline 13. & Nuclear Engineering & $\$ 105,810$ \\
\hline 14. & Civil Engineering & $\$ 84,770$ \\
\hline 15. & Structural Engineering & $\$ 82,845$ \\
\hline & & \\
\hline
\end{tabular}

XIII. CONCLUSION

According to the Central Bureau of Statistics 2014, a total of 4,000,200 people are not getting jobs befitting their qualification and skills. To decrease this rate, it becomes very important for everyone to have a better knowledge of job placements and salary of the field they've chosen.

Engineering is the use of scientific principles to design and build machines, structures, and other items, including bridges, tunnels, roads, vehicles, and buildings. The term engineering itself has a much more recent etymology, deriving from the word engineer, which itself dates back to 1325, when an engineer (literally, one who operates an engine) originally referred to "a constructor of military engines".

In order to be an Engineer, earn a graduate degree, make Networks and work on what you're passionate about. There are now six major branches of engineering: Mechanical, Chemical, Civil, Electrical, Management, and Geotechnical, and literally hundreds of different subcategories of engineering under each branch. Each branch of engineering has a different scope and different work. STEM skill, debugging anything quickly, Logical Thinking and Reasoning, Open mind \& positive attitude, attention, Creativity and Innovation, communication, team player, ambitious, etc. are the main qualities of a successful engineer. You should choose a field only if you've an interest in it and you like being engaged in that.

Having some research and survey about the change in future scopes and salary potential of your field is recommended beneficial. If you don't want to face problems in the upcoming future, consulting your academic advisor for suggestions before choosing your major subject is a better option. The thing that may help you during job placement and work as well and also add a star to your resume is doing an internship during your course or after it. Engineers frequently work to solve problems for people, so it is important to identify when a problem exists, evaluate relevant information, then assess alternatives and impacts, act decisively and re-assess the situation.

Engineering started in Nepal when in 1972, the Nepal Engineering Institute at Pulchowk and the Technical Training Institute at Thapathali were brought together under the umbrella of the Tribhuvan University to constitute the Institute of Engineering and the Nepal Engineering Institute and the Technical Training Institute were renamed as Pulchowk Campus and Thapathali Campus respectively. When an Engineer works in Nepal, he/she earns around 90,700 NPR per month on anerage $(53,400$ NPR minimum and 128,000 NPR maximum).

\section{ACKNOWLEDGMENTS}

"A research article can never be written without the assistance and encouragement of other peoples. And definitely this is not an exception."

I would like to thank all those whose assistance proved to be a milestone in the accomplishment of my end goal. I would also like to present my special thanks to my teachers, especially Ram Sundar Matang (Department of Physics, St. Xavier's College), who helped me deal with the constraints for my research, reviewed this article and supported me to successfully complete this research project, Building a Future Towards Engineering. Also, I would like to express my gratitude to Santosh Mishra, Secondary level Science teacher, for all his efforts. He is the one who helped me at every stage of this project. He was always ready to solve the problems that arose during the research.

I also extend my gratitude to all the staff and teachers of the Department of Physics, St. Xavier's College, Kathmandu, Nepal for giving me the opportunity.

I also acknowledge with a deep sense of reverence, my gratitude towards my parents and members of my family who supported me morally as well as economically.

At last but not the least gratitude goes to my friends, seniors, and elder brothers who directly or indirectly helped me complete this research article.

It is wholeheartedly expressed that your advice for my research proved to be a landmark effort towards the success of this research.

Any omission in this brief acknowledgement does not mean lack of gratitude. 